\title{
Conservation narratives in Peru: envisioning biodiversity in sustainable development
}

\author{
Yves M. Zinngrebe ${ }^{1}$
}

\begin{abstract}
In the mega-diverse country Peru, a resource intensive development model collides with the interest of conserving biodiversity. Peruvian biodiversity experts have developed different lines of argumentation as to how to integrate conservation into the sustainable development of their country. Applying grounded theory, I define five groups of conservation narratives based on the analysis of 72 qualitative interviews with experts working in areas of biodiversity conservation. I have labeled them: biodiversity protectionists, biodiversity traditionalists, biodiversity localists, biodiversity pragmatists, and biodiversity capitalists. These groups are each discussed in connection with what they have to say about biodiversity in relation to human life, valuation and knowledge systems, participation and leadership, substitutability of natural capital, and its predominant political strategy. In a second step, a comparative analysis of the dominant and diverging political perspectives is made. I argue that by deconstructing underlying premises and ideologies, common ground and possible opportunities for collaboration can be identified. Moreover, although the presented results can serve as a discussion scaffold to organize conservation debates in Peru, this example demonstrates how the terms biodiversity and sustainability are operationalized in conservation narratives.
\end{abstract}

Key Words: environmental discourses; extractivism; Latin America; natural capital; political ecology; protected areas; sustainability

\section{INTRODUCTION}

Solving the global problem of biodiversity loss will largely depend on the ability of countries to adopt sustainable paths of development. Mobilizing support for the conservation of biodiversity is particularly challenging in a developing country such as Peru, whose economy is focused on a neoliberal growth model and the extraction of primary resources (Orihuela and Thorp 2013). Several decades ago, Peru's President Belaunde Terry highlighted the economic potential of the Amazonia and called for a "colonization of Peru by the Peruvians" (Belaunde Terry 1994). Resource extraction has clearly intensified since that time. Agricultural land has expanded to cover from just over 2 million hectares in 1995 to over 3 million hectares in 2012 and investments in mining projects grew from about one billion US dollars in 2005 to over 8.5 billion dollars in 2012 (INEI 2015). Deforestation and land fragmentation in the Peruvian Amazon are connected to incentive structures linked to agricultural policy (Chavez 2014). Estimates suggest that the expansion of palm oil plantations has contributed to $1.3 \%$ of total deforestation in Peru from 2000 to 2010 (Gutiérrez-Vélez et al 2011). Mining projects can pose a particularly significant threat to biodiversity (Finer et al. 2008).

In recent years, the struggle for resources has led to an increase in social-ecological conflicts. The independent governmental organization Defensoría del Pueblo observed an increase of 13 social-ecological conflicts in 2005 to 122 in 2014, which they define as contradicting interests over the use of ecosystems that have the potential to escalate and become violent (Defensoría del Pueblo 2015). In a prominent example of a conflict, in 2009 several thousand local Peruvians gathered in the city of Bagua to protest against intensified oil extraction in the Amazon region and liberal economic reforms of the government of President Alan García (2006-2011). The violent escalation led to 33 deaths and approximately 200 injured civilians and police (Bebbington 2013).
Throughout the conflict, García attributed the perro del hortelano (dog in the manger) syndrome to the movement:

It is the old communist, the anti-capitalist of the $19^{\text {th }}$ century, who is disguised as the protectionist of the $20^{\text {th }}$ century and changes outfits in the $21^{\text {st }}$ century pretending to be the environmentalist. But he is always anti-capitalist (El Comercio, 28 October 2007, as cited in Bebbington 2013:34, [Translated from the Spanish]).

The debate in Peru between whether to follow a resource intensive economic development path or to favor environmental protection is often strongly polarized. Peru is party to the Convention on Biological Diversity (CBD) and has developed a substantive biodiversity policy. The country has an updated National Biodiversity Strategy and Action Plan (NBSAP), a national commission for biodiversity, and protected areas that cover more than $17 \%$ of its terrestrial surface area (SERNANP 2016). Local expert knowledge in Peru links biodiversity loss to a variety of direct and indirect causes and effects (Zinngrebe 2016a). Meaning of the political problems of biodiversity loss as well as priorities for political action, however, are defined by the political discourse. Over the past several decades, different conservation movements produced a variety of innovative approaches for incorporating biodiversity conservation into a more sustainable model of development (Zinngrebe 2016b). These movements produce and influence narratives on what biodiversity conservation means in the political context.

According to Forsyth and Walker, "environmental narratives are simplified explanations of environmental cause and effect that emerge in contexts where environmental knowledge and social order are mutually dependent" (2008:17). Different motivations and social and ethical systems produce different narratives that stakeholders apply to frame the situations and problems they perceive as well as their perspectives on possible solutions to those 
environmental problems. This framing is also politically important because it was shown to influence institutional arrangements for policy implementation (Arts and Buizer 2009). The Foucaultian concept of discourse states that actors in a political arena shape meanings and language of environmental problems according to their power and influence (Hajer 1995). Discourse groups differ in the way they "interpret and frame the relationship between nature and human society," which leads to "misconceptions, mismatches and conflicts of interest between and within institutional and governance structures and processes" (Apostolopoulou et al 2012:424). Simplifications of environmental discourses can lead to a marginalization of the plurality of different approaches (Nygren 1998). Clearly, there is a need to develop analytical tools that can help with unravelling, systemizing, and discussing the different approaches to biodiversity conservation.

In this article I deliberately avoid the use of the term "discourse" because it does not evaluate how power structures shape meanings over time. Instead, "narrative groups" are identified by analyzing how Peruvian experts working in biodiversity conservation construct perspectives on sustainable development. Dominant sustainable development narratives can be categorized and deconstructed, and relevant political actors, movements, and strategies associated with them can be identified (Nygren 1998, Apostolopoulou 2012). Based on the analysis of qualitative interviews, I present a conceptual scaffold that enables the structural exploration of the political meanings and approaches incorporated into Peruvian biodiversity policy.

The meanings and objectives of political discourses are shaped by the interaction of political stakeholders. I do not categorize political actors nor assess their influence and power in the political arena. Rather, I identify different perspectives and approaches to confronting complex environmental challenges, and relate those perceptions to the social settings they derive from. Analyzing these biodiversity narratives helps paint a picture of the opportunities and obstacles faced by actors trying to implement abstract concepts such as biodiversity and sustainability.

\section{METHODS}

For this study, a qualitative research design was used to analyze the lines of argumentation of different groups of conservationists (see Fig. 1). The collection of empirical material, coding procedures, and theory building were carried out in parallel, following a grounded theory methodology (Cobin and Strauss 1990, Glaser and Strauss 2009). Five identified narratives were contrasted with four key themes identified in the analytical process.

Seventy-two semistructured interviews were conducted in Spanish by the author from 2012 to 2014 with key actors within the Peruvian biodiversity policy process (Table 1). The interviews were recorded and transcribed. Interviewees' statements were coded and categorized into five different narrative groups (Glaser and Strauss 2009; see Table 2). Initially, participants of the national Commission for Biodiversity, who served as gatekeepers for access to other actors, were interviewed. Respondents were asked to indicate other possible interviewees. With the aim of capturing a "maximal structural variation" in perspectives, the selection of interviewees was spread across institutions and political levels applying a theoretical sampling strategy (Froschauer and Lueger 2003, Flick 2007).
Fig. 1. Overview of methodological process. Biodiversity experts were selected using theoretical sampling. The semistructured interviews were then analyzed in a three-step coding process. Analytical cycles were repeated until further interviews only confirmed established categorization of narrative groups. The established categories were then used to reflect theoretical paradigms from the literature.

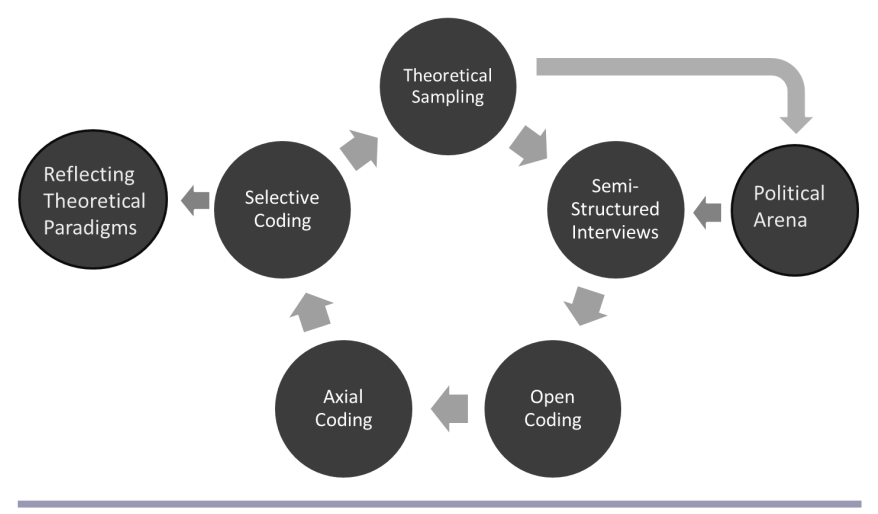

Table 1. List of included interviews separated by represented organisation or the interviewee.

\begin{tabular}{lc}
\hline \hline Organization & $\begin{array}{c}\text { Number of included } \\
\text { interviews }\end{array}$ \\
\hline National Ministry for the Environment & 6 \\
National Agency for Protected Area & 5 \\
Management & 8 \\
Other National Ministries and Agencies & 13 \\
Regional Governments & 3 \\
Local Governments & 8 \\
National NGOs & 5 \\
Local NGOs & 9 \\
International Development Cooperation & 10 \\
Scientists, Consultants, Retired Politicians, & \\
Media & 5 \\
Local Communities & 72 \\
TOTAL: &
\end{tabular}

An open initial question asked the interviewee to explain her own professional perspective about the biodiversity conservation. In the semistructured interview, respondents were asked to state their perspective on the problem of biodiversity loss, involved stakeholders, knowledge systems, and possible political strategies.

From the recorded interviews, statements were labelled using MaxQDA software. Using axial coding, specific key aspects were identified to distinguish different lines of argumentation among the conservationists. After evaluating the first interviews, a draft for the categorization was established. This categorization was further tested and adapted through additional interviews, until the point was reached that the interview contents consistently confirmed the categories already identified (presented in Table 2). In a selective coding process, categorized narratives were characterized according to key aspects (presented in Table 3). 
Table 2. Presentation of narrative groups. The groups are characterized according to the general orientation and the background of proponents, who predominantly apply the respective narrative.

\begin{tabular}{|c|c|c|c|c|c|}
\hline & $\begin{array}{l}\text { Biodiversity } \\
\text { Protectionists }\end{array}$ & $\begin{array}{l}\text { Biodiversity } \\
\text { Traditionalists }\end{array}$ & Biodiversity Localists & $\begin{array}{l}\text { Biodiversity } \\
\text { Pragmatists }\end{array}$ & Biodiversity Capitalists \\
\hline Key Imperative & $\begin{array}{l}\text { Protect biodiversity } \\
\text { hotspots }\end{array}$ & $\begin{array}{l}\text { Protect autonomous, } \\
\text { local life styles }\end{array}$ & $\begin{array}{l}\text { Secure local livelihoods } \\
\text { and healthy ecosystems }\end{array}$ & $\begin{array}{l}\text { Institutional capacity } \\
\text { building }\end{array}$ & $\begin{array}{l}\text { Economic valorization of } \\
\text { biodiversity }\end{array}$ \\
\hline $\begin{array}{l}\text { Predominant } \\
\text { Background of } \\
\text { Proponents }\end{array}$ & $\begin{array}{l}\text { National and } \\
\text { international NGOs, } \\
\text { national government, } \\
\text { often biologists }\end{array}$ & $\begin{array}{l}\text { National NGOs, } \\
\text { indigenous federations, } \\
\text { communities, civil } \\
\text { servants }\end{array}$ & $\begin{array}{l}\text { Regional and local } \\
\text { governments, local } \\
\text { NGOs }\end{array}$ & $\begin{array}{l}\text { National } \\
\text { government, national } \\
\text { NGOs }\end{array}$ & $\begin{array}{l}\text { National government, } \\
\text { international } \\
\text { cooperation }\end{array}$ \\
\hline
\end{tabular}

Generally, narratives were consistent. Only occasionally were some different argumentations taken up in an interview. I translated the included citations from Spanish into English with a focus on contextual messages. The translation was proofread by a native English speaker who is also fluent in Spanish.

\section{RESULTS AND DISCUSSION}

Analysis of the interviews resulted in the identification and characterization of five narrative groups that were labelled the following: Biodiversity Protectionists, Biodiversity Traditionalists, Biodiversity Localists, Biodiversity Pragmatists, and Biodiversity Capitalists (see Table 2 and Appendix 1). The different narrative groups are discussed according to four key aspects (A to D) that were identified in the research process (see Table 3). Narrative themes found in Peru are then linked to global scientific debates.

\section{(A) Conceptualizing biodiversity}

According to the CBD, biodiversity is defined as the "variability among living organisms [...] and the ecological complexes of which they are part" (United Nations 1992:article 2). This wide definition allows actors to set priorities and to differ in the way they connect biodiversity to human life. Mace et al. (2012: 19) describe the variety of functions or "ecosystem services" attached to biodiversity in relation to human life as threefold: "as a regulator of underpinning ecosystem processes, as a final ecosystem service and as a good that is subject to valuation, economic or otherwise." Ecological complexity is further increased by the social construction of human nature interactions in local, cultural settings around the world. For example, biodiversity was described as a fundamental part of collective ethnic identities in the Colombian Pacific, or as linked to six "faces" of traditional ecological knowledge of Canadian First Nations (e.g., Escobar 1998, Houde 2007). These concepts of biodiversity lead to different interests regarding the application of biodiversity policies and political instruments. For instance, the "parks and people" debate emphasizes how concepts of biodiversity leads to differing claims concerning how best to manage protected areas and to improve the resilience of socialecological systems (West et al. 2006, Berghoefer et al. 2010).

The analysis also sheds light on the different objectives that narrative groups pursue. Traditionalists mainly emphasize the importance of biodiversity as an essential part of cultural and social-ecological systems. Many proponents of this perspective work with indigenous federations and local organizations and highlight the economic, cultural, and spiritual interdependencies and rights that link populations to the ecosystems in which they live.
Localists see both biodiversity and protected areas as part of their landscape and as necessary for providing food and resources, and enabling ecosystems to function sustainably. Representatives either work for regional governments or other organizations engaged in projects that have to plan and coordinate conservation with other land-use interests.

Protectionists emphasize the intrinsic and scientific value of biological diversity and call for the conservation of its beauty and potential in separated parks. In contrast to the grassroots perspectives of traditionalists and localists, protectionists justify their perspective with international scientific concepts and refer to the potential of international conservation funds that national NGOs have been using for conservation projects since the 1980s.

Capitalists on the other hand, emphasize ecosystem services as a foundation for economic growth. This concept derives from international political and scientific debates around ecosystem services and is used to convince a growth-oriented political economy of the (economic) value of biodiversity.

Pragmatists work on specific conservation projects focused on reaching specific, and often different, biodiversity targets. They often criticize the absence of precise biodiversity objectives.

The different concepts of biodiversity appeared in different conservation movements that framed biodiversity in relation to the political developments of the time (for background on conservation movements see Zinngrebe 2016b). Narrative groups implicitly refer to specific objectives and conservation strategies. A transparent process is needed to reflect on objectives, opportunities, and limitations of the stakeholders and their diverging conservation strategies. This transparency is needed to enable a legitimate, societal process of defining political biodiversity targets. In situ conservation, for instance, enables the conservation of the genetic variety of a crop, but might not be an adequate strategy to conserve landscape beauty or ecological integrity of a biome in an ecosystem approach. A constructive political debate on conservation requires stakeholders to specify their definitions and also acknowledge the existence of other perspectives and conservation priorities.

\section{(B) Role of stakeholders}

Narrative groups vary in the way they regard the role of different stakeholders in the governance process. "Governance" is here understood as "rules, processes, and behavior that affect the way in which powers are exercised" (Jasanoff and Long Martello 2004:8). Actors within the conservation debate tend to blame biodiversity loss on certain stakeholder groups and also give the 
Table 3. The five identified conservation narratives and their perspectives on four key aspects.

\begin{tabular}{|c|c|c|c|c|c|}
\hline & $\begin{array}{l}\text { Biodiversity } \\
\text { Protectionists }\end{array}$ & $\begin{array}{l}\text { Biodiversity } \\
\text { Traditionalists }\end{array}$ & $\begin{array}{l}\text { Biodiversity } \\
\text { Pragmatists }\end{array}$ & $\begin{array}{l}\text { Biodiversity } \\
\text { Localists }\end{array}$ & $\begin{array}{l}\text { Biodiversity } \\
\text { Capitalists }\end{array}$ \\
\hline \multicolumn{6}{|c|}{ (A) Conceptualizing Biodiversity } \\
\hline $\begin{array}{l}\text { Situating biodiversity in } \\
\text { relation to human life }\end{array}$ & Outside & Integrated & Depending on policy & Integrated & Outside \\
\hline Role of protected areas & Islands without people & $\begin{array}{l}\text { Traditional } \\
\text { environment, direct use }\end{array}$ & Part of policy mix & $\begin{array}{l}\text { Important landscape } \\
\text { characteristic }\end{array}$ & $\begin{array}{l}\text { Generating ecosystem } \\
\text { services }\end{array}$ \\
\hline \multicolumn{6}{|c|}{ (B) Participation and leadership } \\
\hline Role of local people & Ignorant to be educated & $\begin{array}{l}\text { Bearers of local } \\
\text { knowledge }\end{array}$ & $\begin{array}{l}\text { Resource users with } \\
\text { cultural practises }\end{array}$ & $\begin{array}{l}\text { Political stakeholders } \\
\text { and key to } \\
\text { effectiveness }\end{array}$ & $\begin{array}{l}\text { Individual resource } \\
\text { users }\end{array}$ \\
\hline Political level that initiates & International & Local & National & Regional & International \\
\hline
\end{tabular}

change

(C) Valuation and knowledge systems and substitutability economic potentials in nature

Knowledge form and value Academic knowledge on Spiritual and traditional Integrate different

dimension

biological variety

values and knowledge

Substitutability of natural

Unsubstitutable

Unsubstitutable

approaches in

assessments

capital

(D) Political strategy

Dominant Political

instruments

OT and land-use planning
Protected areas, research, regulation

Designation and

expansion of protected

areas
Value of functional

ecosystems and

services

Not Substitutable
Economic potentials in nature

Substitutable
OT = ordenamiento territorial, a a strict land-use planning and governance process.
Empowerment of local communities

Informal process of

local people
Improving institutional capacity uses planning

Instrument for policy Key policy

integration
Technological

transfer, valorization Information resource on potentials responsibilities for leadership in conservation action to certain groups. However, as Forsyth and Walker pointed out, the "distinction between forest guardians and forest destroyers is unproductive and socially unjust" (2008:25). Moreover, already rhetorical practises defining "biodiversity guardians or destroyers" are likely to create polarized and opposing positions, such as global versus local, or economic growth versus green communism, as illustrated by Alan Garcia's statement quoted in the introduction (Jasanoff and Long Martello 2004). In contrast, a closer look at the different positions can help us to unravel an often oversimplified and ideological conflict.

Traditionalists see local people as bearers of traditional biodiversity conservation knowledge, which they have integrated into their cultural practises. They blame international corporations, globalized markets, and extractive industries for negatively altering social-ecological equilibria and thereby have aligned with powerful actors resisting governmental extraction projects in the past, such as the above-mentioned example of Bagua. Traditionalists see conservation as a means to secure social objectives, such as securing rights and economic possibilities for indigenous and local people.

Protectionists critically highlight threats to ecological systems posed by the expansion of the population and accompanying land-use changes. They favor a separation of conservation and economic activities, which can lead to further conflicts as conservation projects compete more and more for land with urbanization and other land-use interests. In contrast to the traditionalists, who tend to reject international involvement, protectionists often come from outside social-ecological systems and seek to implement conservation projects financed primarily by national and international donors. Locally, this has contributed to the population's impression that international interests and the rule of money dominate local land-use decisions.

Biodiversity capitalists argue for raising the awareness of local and economic actors through demonstrations of the economic value of ecosystem services. This rhetoric is primarily targeted at powerful policy makers and economic actors, to convince them to incorporate conservation into their decisions and practices. Public investment projects (PIP) that fund governmental projects on all political levels are allocated according to cost-benefit analyses by the powerful Ministry for Economy and Finance (MEF).

Localists argue that participative land-use management can stimulate leadership in conservation among the local population. They highlight that if concessions and rights for exploitation are distributed on the national level without local consultations, those decisions are unlikely to find understanding among local citizens. Regional governments that have limited capacities to enforce their policies depend, after all, on support by local communities and local organizations.

Pragmatists point to the necessity of developing institutions that allow for the participation of the distinct roles of stakeholders in policy and planning processes. The different narrative groups highlight the different functions of actors in processes of conservation and the destruction of biodiversity. Past analyses of environmental conflicts point to the necessity of creating political 
spaces for the coordination of efforts as a fundamental step toward democratization and institutional innovation in solving ecological conflicts (Bebbington 2013). Following only one terminology might lead to the marginalization of certain minorities. For example, assessing biodiversity as the monetary benefits of ecosystem services might marginalize the interests and conservation practises of the poor (Martinez Alier 2010). In the process of institutional development in Peru, the particular practises and expectations of stakeholders should be acknowledged and incorporated into the governance process to encourage leadership and engagement in conservation activities.

\section{(C) Value and knowledge systems and sustainability}

Valuation and knowledge systems provide norms and measures that are used to define conservation objectives and to decide on trade-offs. The economic debate on sustainability differentiates valuation systems by the level they allow for the substitution of ecological qualities by other (social or economic) dimensions of human development (Neumayer 2003). A strong sustainability paradigm aims at the independent conservation of ecological properties within ecological limits, pointing to tipping points and the risk of losing unique properties of nature. In contrast, a weak paradigm allows for ecological assets to be substituted by other forms of development, as long as the overall capital stock is at least maintained. By measuring natural capital in monetary terms, the weak sustainability paradigm offers the advantage of comparability of costs and benefits in the decision-making process on conservation policies. Inspired by mega projects such as the Stern Report, the Millennium Ecosystem Assessment, or the work on The Economics of Ecosystems and Biodiversity (TEEB), many recent international and national political discourses adopt this paradigm. Outside of the economic debate, anthropological studies for instance have revealed locally dependent value and knowledge systems that define conservation priorities and perceptions of ecological risk in culturally dependent language and measures (e.g., Escobar 1998, Kilbane Gockel and Gray 2009).

In the light of societal pressure toward economic growth and investments, biodiversity capitalists use valuation schemes for ecosystem services to convince different stakeholders, such as the Ministry for Economy and Finance (MEF), or potential donors at the international level, of the economic benefits of conserving biodiversity. This corresponds to a weak sustainability perspective.

Opposing this, protectionists adopt a strong sustainability perspective and aim at conserving biodiversity independently from other aspects of development. They call for more biological assessments of biodiversity conditions and trends. Both narrative groups rely on accumulated indicators that allow visibility of ecological changes at the national or international levels. Outside of the weak versus strong sustainability scale, pragmatists assess advances in the performance of policy and governance mechanisms and their capacity to confront biodiversity loss.

Another game-changing aspect can be found in the local dependence on biodiversity as highlighted by the traditionalist and localist narratives. Traditionalists point to the cultural importance of biodiversity to communities; this makes it critical to preserve traditional knowledge and practises as well as local identities. There is little discussion within this community about ecological limits. Localists call for equilibrium of production and conservation in all local geographies based on the "capacities" of the land, as revealed by land-use planning processes. The way a group argues for conservation based on knowledge and valuation systems sheds light on the primary target group that they are addressing with their argumentation.

As earlier analyses have shown, presenting environmental problems in simplified, positivistic cause-effect relations runs the risk of marginalizing the perceptions of certain stakeholders (Forsyth and Walker 2008), which presents issues of legitimacy and representation. Instead of arguing for a predominant sustainability paradigm, different valuation and knowledge systems can inform the policy process at different stages. In the process of policy design and implementation, "input-legitimacy" requires that conservation objectives and indicators allow for the complexity of stakeholders' concerns and interests to be expressed and negotiated in a transparent and participatory way (Kvarda and Nordbeck 2012). The complexity of language and valuation systems should be elaborated in a way that meets the complexity of narratives present in the political arena and makes as transparent as possible the trade-offs between ecological qualities and other assets of development (Hirsch et al. 2011). Without consciously confronting the issue of trade-offs, biodiversity policies can fail to produce positive environmental effects (Campbell 2002, Campbell et al. 2010). Therefore, a sensitive participatory process that includes different value and knowledge systems in the policy design and evaluation process seems to be a prerequisite for both input and output-legitimacy as well as effectiveness of the implementation process.

\section{(D) Political strategies}

Biodiversity governance can incorporate a variety of policy instruments and other measures that interact to conserve biodiversity. Literature on environmental policy instruments points to the fact that no instrument is in general superior; all have to be adapted to respective problem conditions (e.g., Goulder and Parry 2008). Moreover, often individual projects, traditional practices, and private initiatives promoting sustainable production can take over important functions in biodiversity governance (Berhoefer et al. 2010, Campbell et al. 2010). Local participation and capacity building as part of a decentralization process consistently appear as requirements for effective biodiversity conservation policies (Lutz and Caldecott 1996).

Biodiversity capitalists believe that biodiversity can only be conserved against economic interests, if given an economic value. By pursuing a rather technical approach to developing valorization schemes of ecosystem services and by creating markets for biodiversity products, both local and large producers and political decision makers may be convinced of the economic benefit in conserving biodiversity.

Protectionists are convinced of the necessity of strictly regulating and enforcing the conservation of biodiversity in protected areas. Nevertheless, they have taken up part of the capitalists' logic by promoting alternative development, e.g., with ecotourism or alternative forms of production, with the goal of reducing human impacts in and around conservation areas.

This logic avoids the confrontation of two important preoccupations raised by the other groups. First, the benefits 
generated by alternative development schemes are unlikely to compete with the revenue generated by mining and hydrocarbon extraction or industrial projects (Bebbington 2013). Traditionalists confront this problem by claiming that economic interests from investors from the national or international level decide on the use of their territory.

Second, localists point to the limitation of different uses that can be given to a finite territory. They propose a strict land-use planning and governance process (ordenamiento territorial, OT) that balances economic, social, and ecological considerations. In this regard, localists call for a strong OT process that defines (scientifically) "appropriate" land uses and implements them in territorial policies. It remains to be clarified, however, to what extent "appropriateness" of a land use can be (legitimately) defined by a technical process. OT appears to be a very sensitive issue and the different narrative groups have highly diverging opinions regarding the importance that should be given to this process. To date, all efforts of providing a solid legal framework that defines the responsibilities and political weight of OT have been rejected by the national parliament. Picking up on this issue, pragmatists call for stronger institutions and improved clarification of responsibilities and competencies in the policy implementation process. In the process of decentralization of Peru's multilevel governance system, responsibilities are not sufficiently clarified and institutions are under construction (Bertel 2013).

The different narrative groups present a range of different political strategies regarding biodiversity conservation. Existing experiences show that through exploring and evaluating approaches to policy implementation, governance systems can learn and adapt to the uncertainties that may occur along the way (Pressman and Wildavsky 1984). Accordingly, instead of applying one policy strategy as a silver bullet to all resource users on all levels, the governance process can learn from the plurality of conservation approaches that exist and adopt solutions to meet local needs and conditions. A strengthened institutional basis with defined competencies could provide the needed platforms to effectively implement biodiversity policy and coordinate conservation efforts.

\section{CONCLUSION}

As highlighted in the introduction, drawing a simplified, polarized picture between conservation and economic development is likely to result in misunderstandings and conflicts, as well as a marginalization of biodiversity conservation through the dominance of the economic growth model of development. The strategic plan of the $\mathrm{CBD}$ requires member states to raise awareness for biodiversity (Aichi target 1), integrate biodiversity values into national and local development strategies (Aichi target 2), and involve different stakeholder groups in developing approaches to sustainable production (Aichi target 3). Reaching these targets will require more than a top-down articulation of objectives in a terminology developed in international negotiations. Instead it will require understanding local actor groups and their value systems as well as allowing for local approaches to sustainable development to be incorporated into biodiversity governance.

Looking at the example of Peru, I show how currently predominant biodiversity narratives can be identified and deconstructed. By drawing from the experience of experts working in conservation, I present a unique scaffold for identifying and comparing different perspectives on biodiversity conservation. This can sensitize scientists, practitioners, and other stakeholders to the existence of different mechanisms, values, meanings, and knowledge systems in biodiversity governance as well as illuminate important obstacles and opportunities for improvement. Additionally, this scaffold can be used as a theoretical framework for analyzing political lines of argumentation appearing in Peruvian discourses or documents.

In this paper I identify four essential aspects that ought to be taken into account by conservation policy design. First, different narratives focus on specific, varying aspects of what is referred to as biodiversity. Consciously confronting this issue and transparently specifying those aspects can help to facilitate negotiations and avoid misunderstandings. Second, as recent history has shown, marginalization of certain stakeholder groups inevitably leads to conflict. Transparent institutional mechanisms of participation can help to clarify misunderstandings and identify perceived risks. Third, different value and knowledge systems should be acknowledged, incorporated, and potentially related to other systems to legitimately and effectively define conservation objectives and evaluate their progress. And finally, instead of calling for one-size-fits-all solutions to biodiversity loss, the different approaches present an amplified toolbox for conservation activities that can be adapted to local specificities. Although the different conservation narratives derive from different stakeholder groups at different levels, they are likely to complement each other in a policy process that involves all levels from global to local.

By definition, "effectiveness" of a political process can only be achieved and evaluated in relation to its performance in reaching specified targets. All analyzed narrative groups except for traditionalists pursue a rather technical approach, applying a terminology of "appropriate land use" and assuming the "correctness" of their knowledge system. Instead of insisting on a rational logic behind the need for political action, the results demonstrate the divergence of different approaches and objectives in biodiversity policy. Although the technocratic language might seek to avoid confrontation with the economic growth ideology, eventually only participative democratic decision-making processes can give legitimacy to biodiversity objectives. Such participative processes need conceptual analyses that reveal critical aspects to inform decision processes.

Responses to this article can be read online at: http://www.ecologyandsociety.org/issues/responses. $\mathrm{php} / 8512$

\section{Acknowledgments:}

I want to acknowledge the useful feedback I received at "The International Conference for Sustainable Development Practice" (at Columbia University, New York) and "Qualitative Research Forum" (at Georg August University, Göttingen) prior to submission. I would like to express my gratitude to all the Peruvian conservation experts for sharing their immense experience with me. 
I would also like to thank the unknown reviewers, Miranda Schreurs, Niels Dreber, Thomas Tyrell, Kaiti Tasker, Ulrike Zeigermann, Stefan Schüler, Christine Rumpf, Rebekah Nahai, and Susanne Rewitzer for their useful comments at different working stages of this paper. The research process was funded by Heinrich-BoellFoundation. I acknowledge the support of the Open Access Publication Fund provided by Göttingen University and the German Research Foundation.

\section{LITERATURE CITED}

Apostolopoulou, E., E. G. Drakou, and J. D. Pantis. 2012. Unraveling stakeholders' discourses regarding sustainable development and biodiversity conservation in Greece. Pages 405-430 in C. Ghenai, editor. Sustainable development - policy and urban development - tourism, life science, management and environment. InTech, Rijeka, Croatia. http://dx.doi.org/10.5772/26942

Arts, B., and M. Buizer. 2009. Forests, discourses, institutions: a discursive-institutional analysis of global forest governance. Forest Policy and Economics 11:340-347. http://dx.doi. org/10.1016/j.forpol.2008.10.004

Bebbington, A., editor. 2013. Industrias extractivas - Conflicto social y dinámicas institucionales en la Región Andina. Instituto de Estudios Peruanos (IEP), Centro Peruano de Estudios Sociales, Grupo Propuesta Ciudadana, Lima, Peru.

Belaunde Terry, F. 1994. La Conquista del Peru por los Peruanos. Third edition. Editorial Minera, Lima, Peru.

Berghoefer, U., R. Rozzi, and K. Jax. 2010. Many eyes on nature: diverse perspectives in the Cape Horn Biosphere Reserve and their relevance for conservation. Ecology and Society 15(1):18. [online] URL: http://www.ecologyandsociety.org/vol15/iss1/art18/

Bertel, M. 2013. Multi-level governance in Südamerika: das Dezentralisationsmodell der peruanischen Verfassung. Nomos, Wien, Austria.

Campbell, B. M., J. A. Sayer, and B. Walker. 2010. Navigating trade-offs: working for conservation and development outcomes. Ecology and Society 15(2):16. [online] URL: http://www. ecologyandsociety.org/vol15/iss2/art16/

Campbell, L. M. 2002. Conservation narratives in Costa Rica: conflict and co-existence. Development and Change 33(1):29-56. http://dx.doi.org/10.1111/1467-7660.00239

Chavez, A. B. 2014. Landscape dynamics of Amazonian deforestation between 1986 and 2007 in southeastern Peru: policy drivers and road implications. Journal of Land Use Science 9 (4):414-437. http://dx.doi.org/10.1080/1747423X.2013.807310

Corbin, J. M., and A. Strauss. 1990. Grounded theory research: procedures, canons, and evaluative criteria. Qualitative Sociology 13(1):3-21. http://dx.doi.org/10.1007/bf00988593

Defensoría del Pueblo. 2015. Reporte Mensual de Conflictos Sociales No. 139, Septiembre. Defensoría del Pueblo, Lima, Peru. [online] URL: http://sinia.minam.gob.pe/documentos/reportemensual-conflictos-sociales-ndeg-139-septiembre-2015

Escobar, A. 1998. Whose knowledge, whose nature? Biodiversity, conservation, and the political ecology of social movements. Journal of Political Ecology 5(1):53-82.
Finer, M., C. N. Jenkins, S. L. Pimm, B. Keane, and C. Ross. 2008. Oil and gas projects in the western Amazon: threats to wilderness, biodiversity, and indigenous peoples. PLoS ONE 3(8):e2932. http://dx.doi.org/10.1371/journal.pone.0002932

Flick, U. 2007. Qualitative Sozialforschung- Eine Einführung. Rowohlt, Reinbek, Germany.

Forsyth, T., and A. Walker. 2008. Forest guardians, forest destroyers: the politics of environmental knowledge in northern Thailand. University of Washington Press, Seattle, Washington, USA.

Froschauer, U., and M. Lueger. 2003. Das qualitative Interview: Zur Praxis interpretativer Analyse sozialer Systeme. Facultas wuv, UTB, Wien, Austria.

Glaser, B. G., and A. L. Strauss. 2009. The discovery of grounded theory: strategies for qualitative research. Transaction, Piscataway Township, New Jersey, USA.

Goulder, L. H., and I. W. H. Parry. 2008. Instrument choice in environmental policy. Review of Environmental Economics and Policy 2(2):152-174. http://dx.doi.org/10.1093/reep/ren005

Gutiérrez-Vélez, V. H., R. DeFries, M. Pinedo-Vásquez, M. Uriarte, C. Padoch, W. Baethgen, K. Fernandes, and Y. Lim. 2011. High-yield oil palm expansion spares land at the expense of forests in the Peruvian Amazon. Environmental Research Letters 6:044029. http://dx.doi.org/10.1088/1748-9326/6/4/044029

Hajer, M. A. 1995. The politics of environmental discourse: ecological modernization and the policy process. Clarendon, Oxford, UK. http://dx.doi.org/10.1093/019829333x.001.0001

Hirsch, P. D., W. M. Adams, J. P. Brosius, A. Zia, N. Bariola, and J. L. Dammert. 2011. Acknowledging conservation trade-offs and embracing complexity. Conservation Biology 25(2):259-264. http://dx.doi.org/10.1111/j.1523-1739.2010.01608.x

Houde, N. 2007. The six faces of traditional ecological knowledge: challenges and opportunities for Canadian co-management arrangements. Ecology and Society 12(2):34. [online] URL: $\underline{\text { http:// }}$ www.ecologyandsociety.org/vol12/iss2/art34/

Instituto Nacional de Estadistica e Informatica (INEI). 2015. Economía: sistema de información económica. INEI, Lima, Peru. [online] URL: https://www.inei.gob.pe/estadisticas/indice-tematico/ economial

Jasanoff, S., and M. Long Martello. 2004. Earthly politics. Local and global in environmental governance. MIT Press, Camebridge, Massachusetts, USA.

Kilbane Gockel, C., and L. C. Gray. 2009. Integrating conservation and development in the Peruvian Amazon. Ecology and Society 14(2):11. [online] URL: http://www.ecologyandsociety. org/vol14/iss2/art11/

Kvarda, E., and R. Nordbeck. 2012. Legitimacy and policy effectiveness of national strategies for sustainability in Austria. Pages 69-88 in K. Hogl, E. Kvarda, R. Nordbeck, and M. Pregernig, editors. Environmental governance: the challenge of legitimacy and effectiveness. Edward Elgar, Cheltenham, UK. http://dx.doi.org/10.4337/9781849806077.00012 
Lutz, E., and J. Caldecott. 1996. Decentralization and biodiversity conservation. World Bank, Washington, D.C., USA.

Mace, G. M., K. Norris, and A. H. Fitter. 2012. Biodiversity and ecosystem services: a multilayered relationship. Trends in Ecology \& Evolution 27(1):19-26. http://dx.doi.org/10.1016/j.tree.2011.08.006

Martinez Alier, J. 2010. El ecologismo de los pobres: conflictos ambientales y lenguajes de valoración. Espiritrompa Ediciones, Callao, Peru.

Neumayer, E. 2003 Weak versus strong sustainability: exploring the limits of two opposing paradigms. Edward Elgar, Cheltenham, UK.

Nygren, A. 1998. Environment as discourse: searching for sustainable development. Environmental Values 7(2):201-222. http://dx.doi.org/10.3197/096327198129341546

Orihuela, J., and R. Thorp. 2013. La economía política del manejo de las industrias extractivas en Bolivia, Ecuador y Perú. Pages 59-86 in Bebbington (ed.). Industrias extractivas, conflicto social y dinámicas institucionales en la región andina. IEP, CEPES, GPC, Lima, Peru.

Pressman, J., and A. Wildavsky. 1984. Implementation. University of California Press, Berkeley, California, USA.

Servicio Nacional de Áreas Naturales Protegidas por el Estado (SERNANP). 2016. Nuestras áreas naturales protegida: listado oficial de áreas naturales protegidas. SERNANP, Lima, Peru. [online] URL: http://www.sernanp.gob.pe/

United Nations. 1992. Convention on biological diversity. United Nations, New York City, New York, USA. [online] URL: https:// www.cbd.int/convention/text/

West, P., J. Igoe, and D. Brockington. 2006. Parks and peoples: the social impact of protected areas. Annual Review of Anthropology 35:251-77. http://dx.doi.org/10.1146/annurev. anthro.35.081705.123308

Zinngrebe, Y. 2016a. Learning from local knowledge in Peruideas for more effective biodiversity conservation. Journal for Nature Conservation 32:10-21

Zinngrebe, Y. 2016b. Incorporating biodiversity conservation in Peruvian development - a history with different episodes. DARE discussion paper 1606, Department for Agricultural Economics and Rural Development, Georg-August-Universität Göttingen, Göttingen, Germany. [online] URL: https://www.uni-goettingen. de/de/diskussionsbeitr\%C3\%A4ge-des-departments-ab-heft-4-2007/72592. $\underline{\mathrm{html}}$ 
Appendix 1. Detailed results from the interviews.

\section{PRESENTATION OF NARRATIVE GROUPS}

The narrative groups can be distinguished according to their key imperatives and the actors who most frequently adopt a respective narrative (see table 2 ).

\section{A1.1 Biodiversity Protectionists}

The Biodiversity Protectionists are interested in strengthening and improving conservation policies and project implementation. This line of argumentation is derived from the conservation movement which emerged in the 1980s, when many environmental non-governmental organizations (NGOs) appeared and many protected areas were created. With a strong expansion of protected areas in this time, those NGOs used international funds to initiate conservation projects in and around those areas. According to an NGO founder:

In this, we appeared in the year '82 as a group of young people. We had almost all graduated in biology and had the motivation to spread the concept of conservation of nature farther than just parks. In reality, since the beginning of our organisation, the subject of parks has always been seen as an instrument for conservation.

Members of this group are mainly working in national conservation NGOs or governmental institutions, such as the environmental ministry, the national conservation agency SERNANP, or regional conservation agencies.

The Biodiversity Protectionists primarily see biodiversity, landscapes and unique ecosystems as having intrinsic value, which need to be conserved. In contrast to the Biodiversity Capitalists they reject the notion of biodiversity as a mere resource:

The organic law of natural resources says that biodiversity is a natural resource. And In my opinion biodiversity is not a natural resource.

Since their formation in the early 1980s, the Protectionists have criticised the orientation of Peruvian development. They see road construction, especially in the Amazon region, the expansion of large monocultures, the intensified extraction of primary resources and the 
uncontrolled migration of Andean people into the Amazon region as problematic. Instead they call for an ecosystem approach, as developed by the CBD. Instead of developing and advocating an alternative model for development, they focus their interventions on the improvement of conservation projects and the conservation of biodiversity hotspots.

This perspective primarily situates biodiversity as outside of human socio-economic systems. Rather, proponents demand biodiversity hotspots to be conserved in independent protected areas. Recently, they have complemented their focus with a call for more intervention in buffer zones around the parks in order to reduce the pressure on these areas. An NGO representative stated:

We are also working a bit more in the buffer zones, in the surroundings to avoid pressure on the area. By applying economic incentives we support the management committees. We are also supporting the creation of management tools, such as the management plans ['Planes maestros'], the plans of financial sustainability, ZEEs or the touristic use plansall the tools that SERNANP needs to better manage the protected areas [SERNANP (Servicio Nacional de Áreas Naturales Protegidas) is the abbreviation for the Peruvian Conservation Agency].

Conservation projects in Peru are strongly connected to the international level. NGOs and Ministries receive support from the international level to finance conservation and capacity building projects, such as the development of the biodiversity strategy financed from the international level. Additionally, many policies are developed as a response to international commitments, such as the CBD or as part of free trade agreements. Most interviewees applying a Biodiversity Protectionist rhetoric work in these areas.

Biodiversity Protectionists view the attitudes towards conservation of local actors and representatives from other political sectors as part of what needs to be changed in order to meet conservation goals. Frequently they claim that "people don't understand" or are ignorant of the function and value of biodiversity. In their projects, they aim at educating local people. A representative of a national NGO working in the protected area "Pacaya Samiria" noted: 
In Pacaya Samiria they have formed a management committee, and they are the ones who keep guard so that no outsiders enter to fish paiche, because paiche belongs to them and the lagoon is in the surroundings of their community. We have taught them how to fish, how to do this, how to do that, and now we are helping them get paiche out to markets where it can be sold for a good price [note: Paiche (Arapaima) is a large sweet water fish, widely distributed in the Peruvian Amazonia].

The diversity and complexity of ecological systems is a value that Protectionists feel needs to be protected. They call for more "academic knowledge" of domestic biodiversity and have difficulties in accepting traditional and other knowledge or valuation systems on an equal level. The fact that most proponents are biologists might influence this.

Highlighting the intrinsic value of biodiversity, substituting ecosystems and the value they generate for other forms of capital is not an option to Protectionists. Instead they criticise how governments in the last decades have been selling the country to foreign investors and subjecting the land to industrial booms. The current strategy of economic development of the Amazon region was described by a government official:

There is no sustainability at all in this process, and instead it fragments ecosystems, affects species, divides populations, animal populations, human populations, and in many aspects [...] acculturates people because by selling development as roads and other things while in reality there are other visions. There is no ecosystemic vision, no landscape vision.

The principal policy strategy pursued by Protectionists focuses on reducing pressures on protected areas. They call for more awareness raising activities and political regulation. In relation to the creation of the Ministry for the Environment a civil servant commented:

An environmental policy, a printed agenda - that was how we articulated the topic [biodiversity conservation] to the different actors. That was how we worked [in the time before the creation of the Environmental Ministry]. When we turned into the Ministry for the Environment we all thought this was the optimal opportunity to apply sanctions. 
Because one thing is to coordinate and another one is to say "stop! until here no more". [...] And that is what now is expected from the Environmental Ministry regarding biodiversity.

Accordingly, protectionists also call for a strong Ordenamiento Territorial (OT) that takes into account processes of population development and migration, oil and forest concessions and other land-uses when defining areas for conservation.

[note by the author: Ordenamiento Territorial (OT) is defined in the RESOLUCIÓN MINISTERIAL $\mathrm{N}^{\circ}$ 135-2013-MINAM as "the participative political, technical and administrative process of organized occupation, sustainable use, promotion of localization and sustainable development of the human settlements and of economic and social activities and physical development, based on the identification of potentials and limitations, taking into account environmental, economic, socio-cultural, institutional and geopolitical criteria". Zonificación ecológica y economica (ZEE) is the technical process of land-use categorization based on ecological and economic information. (DS $\mathrm{N}^{\circ}$ 087-2004-PCM). ZEE serves as a technical input to the OT process.]

\section{A1.2 Biodiversity Traditionalists}

Proponents of this paradigm perceive economic changes and globalisation as the roots of biodiversity loss. According to an NGO representative, current development paths are seen as problematic, since they do

'not resolve the issues of values, spirituality and joint models of living. We have to find other ways. I don't know if the way of the communities is the only way, but for now that is my proposal.'

Instead Proponents think that the indigenous, local population knows best how to conserve their biodiversity and demand more support for local, autonomous conservation measures. Members of this group are mainly from indigenous organisations, or local NGOs, but also working in other national governmental or non-governmental organisations where they focus on their areas of expertise and interests.

Biodiversity is seen as integrated into cultural systems and production practises. As traditional people are part of their land, their land is part of them. Applying this narrative, a proponent explains: 
Who has made biological diversity possible in Peru? Technicians or indigenous people? Everything we have seen until now, everything of plant diversity, all that hasn't been a gift from nature, it is an expression of the work of the indigenous people.

As such, proponents blame international stakeholders, such as the World Bank and cooperation organisations as well as international corporations for biodiversity threatening activities, such as agricultural expansion, monocultures and fossil fuel extraction. On the contrary, traditionalists follow a very political perspective on the biodiversity problem and criticise the process of privatisation that led to a redistribution of land from many small farmers to a few big enterprises. Some proponents even blame international conservation NGOs of converting indigenous lands into international conservation areas and thereby expropriating local people.

Despite their rejection of the projects run by international enterprises or development organisations, traditionalists frequently refer to international legislation as supportive of their goal. Examples are the article 8j of the CBD on traditional knowledge and the article 391 of the Andean community for access to natural resources is frequently referred to in lines of argumentation.

Migrants from the Andes are frequently blamed by Amazon natives and indigenous federations and other actors for their practises of extensive deforestation through the conversion of rain forest into cattle pastures and agricultural land. Here an example from an indigenous representative:

A bit of change is evident in how, in some places, people have begun to gain an understanding of the importance of conservation. Because it is true that those areas you see over there are deforested areas because of the people, the family of the Andes. When there was this project of this road into the jungle that is often talked about, people came without an idea of conservation. They came with an idea of cutting trees.

Traditionalists refer to culturally grown value and knowledge systems for the human nature relationship. As such, they enable the traditional life styles that offer for example nutritional security, as a Shipibo explains: 
The people of the Shipibo, they lived happily, sawing Yucca, sawing banana, sawing mais, sawing sugar cane, fishing in the lagoon, all that existed in the community. You didn't have anything to eat? You seized the fishing hook and went to fish [...] In their farm they had an abundance of Yucca, an abundance of banana, they had everything. The problem now is that the people do not think about producing with the soil, they think first of all in more money. I buy, I don't sow! For that reason I need money every day.

As can be taken from this quote, some traditionalists do not only fear the direct impacts of globalisation, but also ideological changes that bring insecurity and dependencies. This is criticised, by an NGO member:

I don't care about individualism. I am annoyed about the dependence for eating, for bathing, to dressing, for everything. Just to be another part of a global market. It is important to fight for autonomous communities that can be interdependent among themselves; the few communities that remain like this remain in the Amazonia and in the Andes.

Furthermore, traditionalists argue against predominant knowledge and valuation systems in media and political discourses that do not permit the communication of traditional knowledge. Values, spirituality and cultural interconnections make socio-ecological systems unsubstitutable for other forms of capital or development. However, some traditionalists mainly focus on the legitimate share of benefits for communities in economic development and participation in decision making processes.

As biodiversity is part of their socio-ecological systems, proponents of this paradigm also find traditional practises of indigenous and local people to be the most suited political strategy for conservation. Accordingly, NGOs and governments from different levels should help empowering and strengthening the communities in their institutional organisation and in the realisation of conservation activities. This will require responsibility from local people as described in the statement of an indigenous person: 
The thing would be, every one of us, as citizens, as indigenous, as community members put our hands to our chests and say "stop this now", at least I have to sow a tree, at least I have to take care of the water, at least I have to take care of my environment to be able to live better, both for me and for my children [...]. That means that the institutional part, in this case regional governments, municipalities, NGOs, have to be a complementary to what each community member wants to do. If it is about reforestation, give me some funding, logically to be able to strengthen his working capacities, but our vision has to face the future, No more felling trees, but reforest them.

Regarding advances of conservation, proponents point to innovative conservation modalities, such as the creation of community conservation areas. As a result of long negotiations between local communities, indigenous organisations and the responsible governmental institutions, a comanagement of protected areas could be achieved. However, the lack of funding for administration and implementation of conservation policies is seen as an important challenge. It appears that traditionalists are against a binding OT (land-use planning) process on higher political levels. Instead they prefer to maintain autonomy on the community level.

\section{A1.3 Biodiversity Pragmatists}

The Pragmatists see biodiversity policy as an incomplete process of institutional development. While they consider the orientation and legal basis for biodiversity protection in place, they see problems in policy implementation and instruments for coordinating different interests. As an NGO conservation expert stated:

You have very young institutions both at the national and at the regional level [...] that are not yet done consolidating their competences and their area of activity. The institutions are still very weak. And you can see that in the conflicts - mostly over mining projects. Environmental issues arise in parallel due to a lack of credibility of the institutions that are not able to solve the problem.

Proponents of this paradigm do mainly work in national political institutions, national NGOs or media. Feeding on years of experience in the area of conservation, they see mainly the political 
arena, not the economic arena or single projects, as responsible for bringing about changes in biodiversity practise.

When asked to define or situate biodiversity, they generally quote official, legal documents and their definitions. According to the variety of international and national policies, they acknowledge different integrated and protected area approaches to conservation. However, they blame flaws in the implementation and the coordination of actors for insufficient achievements. An NGO representative demands that conservation policies must fit local situations to be effective:

An opportunity I have seen for Andean agriculture is the organic production and exportation of native products. What we have in the Andes are very small extensions of three to five hectares, no more - and often less than that. But you'll find a very high cultivated biodiversity. On one "chacra" [, a small farm] you'll find 200 species of potato, 50 species of "mashua", five species of maize, ten species of quinoa in only one hectare, in one area of cultivation only. And the vision of the central government is focused on [the cultivation of] monocultures in bigger extensions, which collides with the vision of the Andean agriculture. And this almost "anti-cultural" vision is what creates more poverty [note: Mashua (Tropaeolum tuberosum) and Quinua (Chenopodium quinoa) are native Andean crop species].

Despite the plurality of different stakeholders in the poliltical arena, Pragmatists point to the central, national government as responsible for coordinating those interests and communicating transparent and coherent political orientations. As part of this challenge, an employee of a governmental conservation agency points to the importance of transparent communication:

The other problem we have is our language. The language we use to convince our fellow citizens, our political citizens, has always been a very technical language that wasn't very well understood. That marks the difference here. The language used in the Rio conventions, such as the decisions of the Conferences of the Parties, the Convention of Biological Diversity, is more straightforward. 
More than focussing on specific value or knowledge systems, Pragmatists call for the development of mechanisms to coordinate different interests and political responsibilities, potentially in a land-use planning process (as part of OT). This rational coordination of interests needs to be based on knowledge generated in studies:

There is growth, there are services, the country has to offer, such as health, education, and a lot of things for which we have to sacrifice a certain amount of resources. [...] The country has to do a land-use categorisation. Even though there are metal reserves, I still won't dig holes all along the Andes. And even though we have biodiversity we won't install protected areas everywhere. That is also a barbarity. This needs a study, an analysis. Well, you have a car, you have internet, you have metals - where did that come from? Out of the air? No, it comes from the mines and in this aspect you need to have a balance.

Accordingly, Pragmatists do not stringently believe in the unsubstitutability of biodiversity, but want to coordinate interests of sectors, who are each managing their responsibilities in independent mechanisms as shown in the following quote:

But the OT is also a planning tool of the central government to be able to balance this whole issue of using natural resources and also to put brakes on the [political] sectors [...]. Thus, to have only one map that aggregates the visions of the sectors would be most appropriate. However, in the government we have, every ministry has its own map.

The Pragmatists see contradictions in current sectoral policies and call for practical instruments, such as general land-use planning, standardised Environmental Impact Assessments and greener regulations for the approbation of governmental funds. As a key political strategy, stronger institutions shall help to implement and enforce policies, acknowledge land titles and give a clear orientation both for conservation activities and for exploitation and investment.

\section{A1.4 Biodiversity Localists}

Similar to Pragmatists, Localists thrive for the coordination of interests on the local level as well as the practical elaboration of policy instruments and the enforcement of regulations. However, 
having experienced developments of deforestation and degradation, ecological limits and limited territory is central to their perspective. In order to advance in these aims, they see land-use planning as a central tool to biodiversity policy:

What I want is quality of life. What I certainly want is production - but I work applying my territorial approach. In other words, there has to be equilibrium between the economic, the social, the productive, the environmental and the politically institutional. If I don't have equilibrium, I am simply outdated. And the only thing that will offer me this equilibrium is the backbone, which is OT.

Proponents are mainly regional and local politicians and civil servants, representatives of local NGOs and park managers among others.

Localists situate biodiversity as the biological aspect critical to the functionality of ecosystems. Protected areas and other conservation efforts are not only instruments to protect biological variety; they also provide ecosystem services as a basis for local quality of life:

The areas of conservation don't have to be regarded solely as areas to conserve biodiversity.[...] But to conserve biological diversity, to conserve forests as an essential part of this whole ecosystem that in the end provides water, food and many things the people need to live.

While many different interests of different political and economic stakeholders collide in local land-use conflicts, proponents see inclusion and participation as key to effective policies. Transparent perspectives on land-use and political orientation are a crucial prerequisite to motivate actors to invest, as stated by a representative from a local government:

We need an articulated policy from the ministries and associations of producers [...], including the civil society. Because if they are not determined that biodiversity is important, it does not help to talk and develop policy objectives [...]. I think that participation of the population is key in this whole process. 
With their understanding of different ecosystems and their geographical diversity, Localists call for the collection, organisation, and mapping of knowledge on biodiversity. The ZEE is seen as an important prerequisite that serves as a basis for OT [see section A1.1 for an explanation of ZEE]. A civil servant from Arequipa states:

To conserve biodiversity we need to manage the territory and we need appropriate information to do so, to have a categorisation of the territory, and as part of this categorisation we can prioritise conservation issues.

Due to the rapid increase in the extraction of natural resources in Peruvian regions, proponents of this paradigm point to the urgency of improved regulations:

I honestly think that if we don't do anything now, in ten years from now we'll have to put tanks in front of the reserve, in the whole border - war tanks to prevent that people enter... because the pressure and peoples' necessity for territories and water will be that strong.

Thus, Localists regard biodiversity as crucial for the provision of ecosystem services, as a limited resource and as unsubstitutable.

To date, regional and local policies are dominated by an orientation towards expansion and extraction as explained by an employee of a regional government project:

The priority of the governor is not to [ecologically] recover the territory, but to execute construction projects. And that is because it is easier to get something out of it - do you understand - to receive an economic benefit from the project for me as governor, as manager.

Local conservationists strongly criticize this perspective as unsustainable and short sighted. Instead they propose clear territorial projections that allow actors to act inside transparent limits and regulations. In the future land-use is likely to change due to mining or oil extraction projects, thus land owners will be reluctant to invest in economic projects on their territories. Therefore, 
Localists regard integrated and participative land-use planning and management as principle political strategies for effective biodiversity conservation.

\section{A1.5 Biodiversity Capitalists}

Proponents of biodiversity as inputs for development follow the predominant growth ideology which takes extractivism as a given. They emphasise the necessity of mining and the expansion of agricultural production and infrastructure. The Ministry for Economy and Finances (MEF) allocates funds according to cost benefit analyses based on monetary values. Accordingly, proponents believe that if biodiversity policies want to be effective, they have to be adapted to this logic, as argued for by the former Minister for the environment:

Have in mind that everything has to be oriented economically. It passes through the wallet. Because, if you don't have economic numbers, the Ministry for Economy won't give you money. That I learned VERY WELL. Why did they increase the budget of the protected areas in the Ministry for the Environment? Because it could be demonstrated that there is ecotourism, that tens of thousands of tourists come to visit. It is profitable, it creates local jobs etc. When I demonstrated with SERNANP that the National Reserve Paracas leaves at least 12 million Dollars per year in the Pisco province as benefits for the local population, hotels and restaurants, tourist guides, boats etc, the ministry for Economy and Finance said "Wow, that is good. It produces revenue".

Proponents of this group usually work in governmental organisations and ministries or in international cooperation organisations in Lima and dominantly have an educational background in economics.

Advocates do not situate biodiversity characteristics as part of local culture or social systems. Rather, they speak of "stocks of species", "natural resources" and "possibilities for economic development". Protected areas are framed as a pool of resources and possibilities for local and regional economic structures. Economic benefits, generated by those areas are used to justify conservation practises, as is displayed in the following statement from a civil servant working in the protected area agency: 
Because we conserve in order to use. We do not conserve to just leave it there. We need a sustainable use of the resources. You know that in the Amazonia, the proteins for nutritional purposes is mainly produced with fish, fish from the rivers, most of which derive from protected areas.

Political institutions are expected to convince stakeholders to integrate conservation into their activities. Instead of questioning or confronting powerful industries with a strong impact on biodiversity, such as mining, fishery or agricultural lobby groups, or foreign investments, they call for the development of technical tools to incorporate conservation into existing processes. These instruments are mainly adopted from the international level. Primarily local mismanagement or illegal processes, such as illegal logging, informal mining or coca production, are mentioned as causes for biodiversity loss. A simple logic of ecological destruction as consequence of a utilitarian perspective is applied, as illustrated in the following quote:

"I have to cut down my trees, because that's what gives me the benefits and resources necessary to buy, let's say, a TV". Well, luckily the international community reflected on that and says: "well, of course that carbon capture and those trees should have a value, or conserving those trees should... let's create the REDD initiative or carbon credits or..." Now the task is to define how this money gets to the people...

Accordingly, it is assumed that people prioritise economic activities over conservation. A director of a regional governmental agency states:

How do I benefit from maintaining this park, forest, if I cannot drive from here to Pucallpa - if I do not have the [appropriate] life conditions of a province?

Proponents refer to a "Western logic of sustainability" that shall be used to promote a more sustainable form of development. Economic valuation mechanisms, developed at the international level, such as carbon credits and REDD (Reducing Emissions from deforestation and Forest Degradation), BioTrade or instruments linked to TEEB (The Economics of Ecosystems and Biodiversity) process shall be used to incentivise the population to engage in conservation activities. 
The logic of biodiversity for growth implies that the value of ecosystems and its components can be expressed in economic terms. Conservation interests can be included and balanced with economic projects in accounting procedures of the Ministry for Economy and Finance. The following quote from a ministerial employee illustrates the equation of biodiversity with prosperity:

It is a fact that this effort of [economic] valuation enters national accounting procedures. Thus, the very state benefits by showing off a cleaner image and it appears much more stable with many more reserves. [...] Another is that comparative balances can decide if exploitation of other things shall be allowed or the forest conserved.

Proponents acknowledge that biodiversity is at risk, but they do not want to speak of ecological limits of economic activities. Thereby, they take a position of weak sustainability, which accepts the substitutability of natural capital by other forms of capital. Only little regulatory weight is given to planning processes, such as OT, as can be seen in a quote from the minister for environment:

First, Land-use Management is a planning tool to define the best use of the territory, but in a dynamic way, not a static one. Second, land-use management is a tool to coordinate, not to destroy. Hence, I feel that the political debate that exists in Peru between the national government and regional and local governments leads many to wrongly think that with OT would restrict land uses and say "I don't want this activity, or the other one."

Instead of integrating biodiversity conservation into a holistic perspective of development, political strategy of proponents prefer to develop individual political instruments and tools and therefore separate biodiversity policy from the general course of development. Consider the statement of the current environmental minister:

I don't think one should have to make the intent to integrate all those elements. What we have to do is make efforts to have them and use them in every decision to make it a good 
one. We need OT, definitely. But to have OT, we need information and to have good information we need a good base line and therefore for example, environmental evaluation is a fundamental strategy. Until then, I think we need to have those instruments available to make the information well sustained. We should not try to integrate everything by force, we need to develop each of those instruments.

In order to integrate the conservation of biodiversity into economic development, efforts to valuate costs and benefits, sensibilisation and technological improvements should help to raise environmental awareness. 